\title{
UNDERESTIMATION OF PRIMARY PRODUCTION AS INDICATED BY MEASUREMENTS WITH SIZE-FRACTIONATED PHYTOPLANKTON IN LAKE MAARSSEVEEN I (THE NETHERLANDS)
}

\author{
B.J.G. FLIK, M. BOS, K. ROYACKERS and J. RINGELBERG
}

KEYWORDS : Primary production; phytoplankton size fractionation; herbivorous zooplankton; grazing.

\begin{abstract}
Primary productivity of four size classes of phytoplankton $(<150 \mu \mathrm{m},<50 \mu \mathrm{m},<20 \mu \mathrm{m}$ and $<5 \mu \mathrm{m}$ ) was measured from March through October 1986 in Lake Maarsseveen I with an intubator technique. The mean column production was approximately $400 \mathrm{mg} \mathrm{C}^{-\mathrm{m}^{-2}}$,day-1, with a range of values between 150 and $750 \mathrm{mg} \mathrm{C.m}^{-2}$.day ${ }^{-1}$. The mean contribution of the size fractions $<50 \mu \mathrm{m},<20 \mu \mathrm{m}$ and $<5 \mu \mathrm{m}$ to the size fraction $<150 \mu \mathrm{m}$ was $80 \%, 60 \%$ and $35 \%$, respectively. During their appearance the grazing impact of small herbivorous zooplankton, e.g. rotifers, can give an underestimation of the size fraction $<150 \mu \mathrm{m}$. An indication of this phenomenon is given.
\end{abstract}

\section{INTRODUCTION}

In recent years, considerable attention has been given to research on primary production of various size fractions of natural phytoplankton populations (e.g. BRUNO et al., 1983; KALFF, 1972; MALONE and CHERVIN, 1979; MCCARTHY et al., 1974; MUNAWAR and FAHNENSTIEL, 1982; RAI, 1982; SKJOLDAL and LANNERGREN, 1978; TAKAHASHI and BIENFANG, 1983). The goal of these investigations was not only an understanding of the dynamics of natural phytoplankton assemblages, but also an interest in the phytoplankton. zooplankton interactions in the pelagic ecosystem (RAl, 1982).

It is important to know both the kinds of algae and the quantities available as source of food for herbivorous zooplankton. Further, the productivity of various size classes is extremely important, since preferential grazing by zooplankton is known to occur. In particular, nanoplankton - those algal forms, which pass through nets or screens with a mesh size of 20-65 $\mu \mathrm{m}$ (SKJOLDAL and LANNERGREN, 1978) - form a prominent part in the food for the zooplànkton (GLIWICZ and HILLBRICHT-ILKOWSKA, 1972; GLIWICZ, 1975; HULSMANN, 1983; MALONE and CHERVIN, 1979; PORTER, 1973; RINGELBERG, 1981b). Perhaps for that very reason, this phytoplankton group has been focus of intensive research efforts in recent years. Further, in oligotrophic waters, the nanoplankton often form a major share of the total primary production of the open water masses of aquatic ecosystems (PAVONI, 1963; GLIWICZ, 1969). The productivity of this group may amount to $60-100 \%$ of the total primary production (KALFF, 1972; McCARTHY et al., 1974; MUNAWAR and FAHNENSTIEL, 1982; RAI, 1982; RINGELBERG, 1981b; SKJOLDAL and LANNERGREN, 1978).

During her study of food uptake by selected species of zooplankton from Lake Maarsseveen I, HULSMANN (1983) found that the larger zooplankton predominantly feed upon two species of Cryptomonas both belonging to the nanoplankton. The smallest one 
(5. $10 \mu \mathrm{m}$ ) has a very constant population density throughout the year, except during the winter period. Further, RINGELBERG (1981) for the month of August, mentioned that the size fraction smaller than $30 \mu \mathrm{m}$ to which these cryptomonads belong, accounts for $96 \%$ of the total primary production. Because of the work of HULSMANN (1983), and the beginning of a new investigation on the impact of zooplankton on the primary production in Lake Maarsseveen I, the productivity of various size fractions was studied during 1986. These studies were intended to supplement existing information and to provide a better understanding of energy flow through planktonic ecosystems by quantifying the activity of the various size fractions.

\section{MATERIALS AND METHODS}

Over the period March through October 1986, carbon uptake was measured in four size fractions of the epilimnetic phytoplankton of Lake Maarsseveen I. A description of this meso-oligotrophic lake has been provided by RINGELBERG (1981). Samples of phytoplankton were taken at various depths (every meter from $0.5 \cdot 9.5 \mathrm{~m}$ ) throughout the epilimnion, and subsequently mixed. The samples were transported to the laboratory in Amsterdam and kept overnight in darkness at lake temperature. This procedure was outlined in detail by FLIK (1986). Before storing, the sample was filtrated over $150 \mu \mathrm{m}$ mesh to remove the larger zooplankton.

The following morning, three additional size fractions were obtained by gravity filtration of the sample through $\mathbf{5 0}$ and $\mathbf{2 0} \mu \mathrm{m}$ Monylplankton gauze, and a $\mathbf{5 \mu m}$ nuclepore filter, successively. ${ }^{14} \mathrm{C}$ incorporation was measured after 3 hours of incubation at 8 different light intensities and, for each of the size fractions, $P$. I curves were determined. The measurement of ${ }^{14} \mathrm{C}$ assimilation and the enumeration of the total phytoplankton assemblage were performed as described by FLIK and KEYSER (1981) and FLIK (1986). Values from the resulting P.I curves were used in a mathematical model to calculate the daily primary production. This model has been described by VERMIJ and FLIK (1983), VERMIJ et al. (1985) and DE ROOS and FLIK (1985). It was developed to give a better estimation of the daily primary production of a water column under one square meter.

\section{RESULTS}

To assess the validity of the model for primary productivity, DE ROOS and FLIK (1985) calibrated the model in 1984 against a data set taken from in situ measurements made in Lake Vechten (The Netherlands). The results of this model calibration are shown in Fig. 1.

A preliminary experiment was performed to compare an unfiltered algal assemblage, with a $<150 \mu \mathrm{m}$ and a $<30 \mu \mathrm{m}$ size fraction. In Table 1 absolute and relative cell numbers in these fractions are given for several species. It is concluded that filtration over a screen of $150 \mu \mathrm{m}$ mesh size does not affect the composition of the algal assemblage. On the other hand, the large colonies of Asterionella formosa and Melosira italica are rather good retained by a $30 \mu \mathrm{m}$ screen, since relative cell numbers decl ine from 21.5 to $4 \%$ and 39.5 to $19 \%$, respectively. The decrease in Melosira was less, undoubtedly because the elongated colonies easily break into small parts, thus passing through the $30 \mu \mathrm{m}$ screen. The uptake of $14 \mathrm{C}$ of the $<150 \mu \mathrm{m}$ fraction was similar to that of the unfiltered assemblage. Determined at 8 different light intensities a mean ratio $14 \mathrm{C}$ uptake $<150 \mu \mathrm{m}$ to $14 \mathrm{C}$ uptake 'total assemblage' of 0.996 ( $S=0.077$ ) was found. Since this experiment was performed in March, 1983, the impact of zooplankton grazing can be excluded. The $150 \mu \mathrm{m}$ fraction can be regarded as representative of the total phytoplankton assemblage.

For the period March through October, 1986, P-I curves were determined for the size fractions $<150,<50,<20$ and $<5 \mu \mathrm{m}$. Several authors have experimented with similar size 
classes (DURBIN et al., 1975; RAI, 1982; McCARTHY et al., 1974; MUNAWAR and FAHNENSTIEL, 1982). Moreover, previous results have shown that these fractions give major differences in production. Estimations of the total column production for various sampling days were made for each of the four size fractions. The results for the $<150 \mu \mathrm{m}$ fraction are presented in Fig. 2. The mean column production in the 8 month-period of

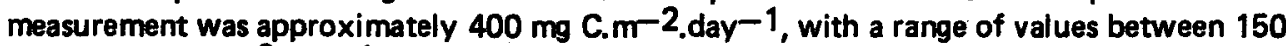
and $750 \mathrm{mg} \mathrm{C.} \mathrm{m}^{-2}$.day-1.

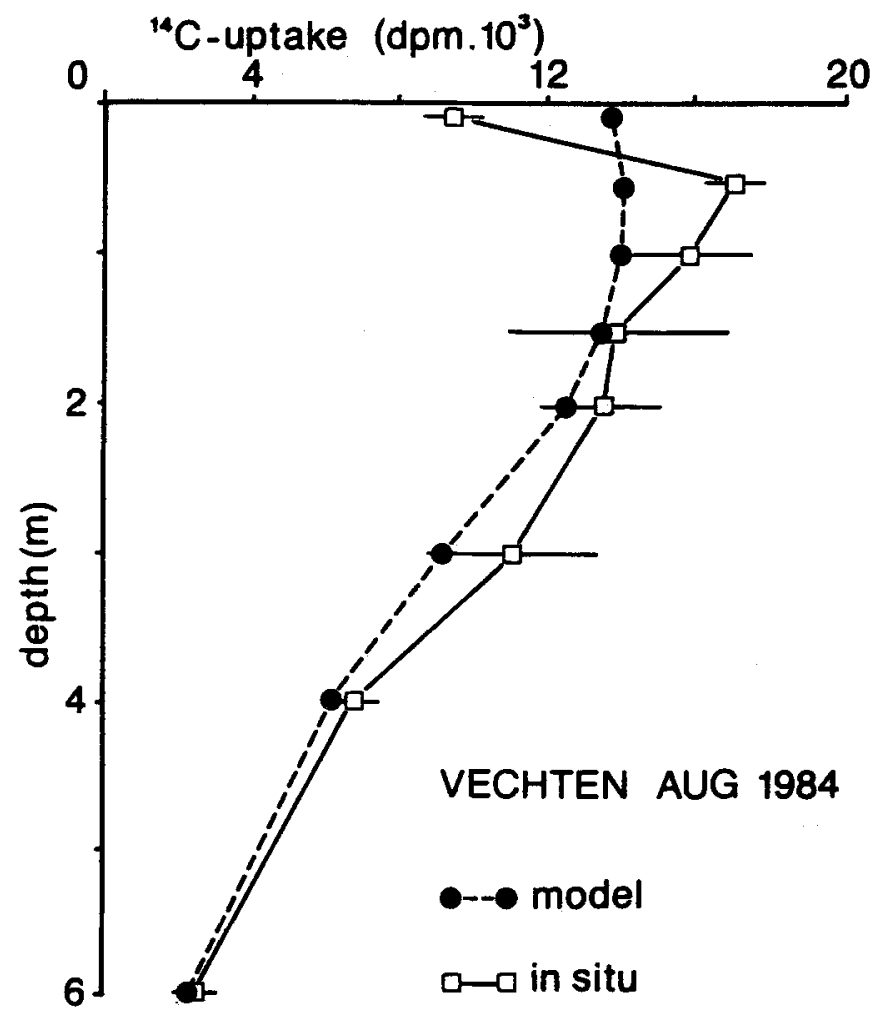

Fig. 1. Depth profiles of carbon uptake, simultaneously measured with laboratory- and in situ incubation techniques.

\begin{tabular}{|c|c|c|c|c|c|c|}
\hline & \multicolumn{2}{|c|}{ Total sample } & \multicolumn{2}{|c|}{ Fraction $<150 \mu$} & \multicolumn{2}{|c|}{ Fraction $<30 \mu$} \\
\hline & Cells.ml-1 & $x$ & Cells.ml-1 & $\%$ & Cells:mi-1 & $\%$ \\
\hline $\begin{array}{l}\text { Total assemblage } \\
\text { Asterionella formosa } \\
\text { Melosira italica } \\
\text { Stephanodiscus astraea } \\
\text { Stephanodiscus astraea var. minutula } \\
\text { Uroglena sp. } \\
\text { Cryptomonas div. spp. (small) } \\
\text { Cryptomonas div. spp. (large) }\end{array}$ & $\begin{array}{r}1995 \\
430 \\
788 \\
121 \\
53 \\
9 \\
560 \\
34\end{array}$ & $\begin{array}{c}21 . \overline{5} \\
39.5 \\
6 \\
2.5 \\
0.5 \\
28 \\
2\end{array}$ & $\begin{array}{r}2044 \\
425 \\
797 \\
128 \\
73 \\
14 \\
569 \\
38\end{array}$ & $\begin{array}{l}21 \\
39 \\
6 \\
3.5 \\
0.5 \\
28 \\
2\end{array}$ & $\begin{array}{r}1031 \\
40 \\
196 \\
106 \\
78 \\
12 \\
571 \\
28\end{array}$ & $\begin{array}{c}4 \\
19 \\
10 \\
7.5 \\
1.5 \\
55 \\
3\end{array}$ \\
\hline
\end{tabular}

Table 1. Cell numbers (absolute and relative) of the total algal assemblage and the $<150$ and $<30 \mu \mathrm{m}$ size fractions. 


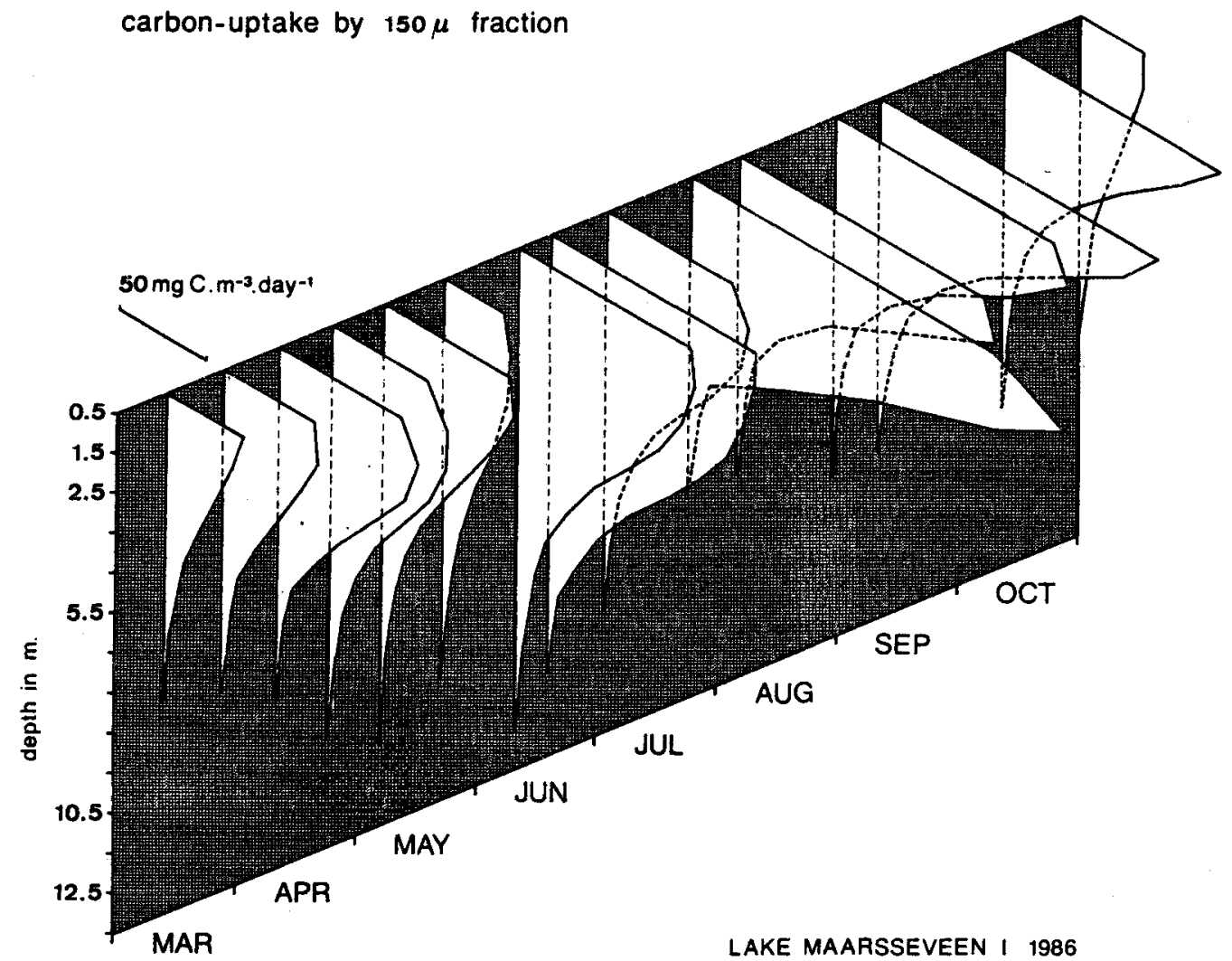

Fig. 2. Depth - time distribution of carbon uptake by $<150 \mu \mathrm{m}$ fraction.

Fig. 3 represents the primary production of the three smaller size fractions as a percentage of the primary production of the $<150 \mu \mathrm{m}$ fraction. The mean of the daily production of the fractions $<50,<20$ and $<5 \mu \mathrm{m}$ were 330,250 and $140{\mathrm{mg} \mathrm{C} . \mathrm{m}^{-2} \text {.day }}^{-1}$, respectively. Expressed as a mean percentage of the total production, these values were 80,60 and $35 \%$ with ranges of $48.98,39-89$ and $20.51 \%$, respectively. Cell counts were made on the 150 $\mu \mathrm{m}$ size fraction to obtain an estimate of the species composition. Table 2 provides the results of these enumerations for the various sampling days in percentages of the total number of algal cells present.

During the summer season, the small species, e.g. cryptomonads, chlorococcids and chroococcids, dominated the phytoplankton community. The bluegreen algae Aphanocapsa sp. was present then in colonies consisting of $100-100,000$ cells. The influence of these algae can be large in the smaller size fractions, since the colonies disintegrate easily to single cells with diameters in the range of $<5 \mu \mathrm{m}$ during pre-screening. For the months July and August, the $P$. I curves of the distinct size fractions suggest that the 50 and $20 \mu \mathrm{m}$ fractions occasionally had a higher carbon uptake $\left(P_{\max }\right)$ than the $150 \mu \mathrm{m}$ fraction. An example of this phenomenon is given in Fig. 4. However, this did not result in column productions exceeding that of the $<150 \mu \mathrm{m}$ fraction (Fig. 3 and Table 3). This is a consequence of the use of the model. The slope $a$ of the $P$ - I curve at the origin determines the outcome of the calculations to a large extent, especially so when low light intensities prevail.

In the cases mentioned, the $150 \mu \mathrm{m}$ fraction had a higher $a$ value, thus resulting in a productivity exceeding that of the 50 and $20 \mu \mathrm{m}$ size fractions at the prevailing irradiances 


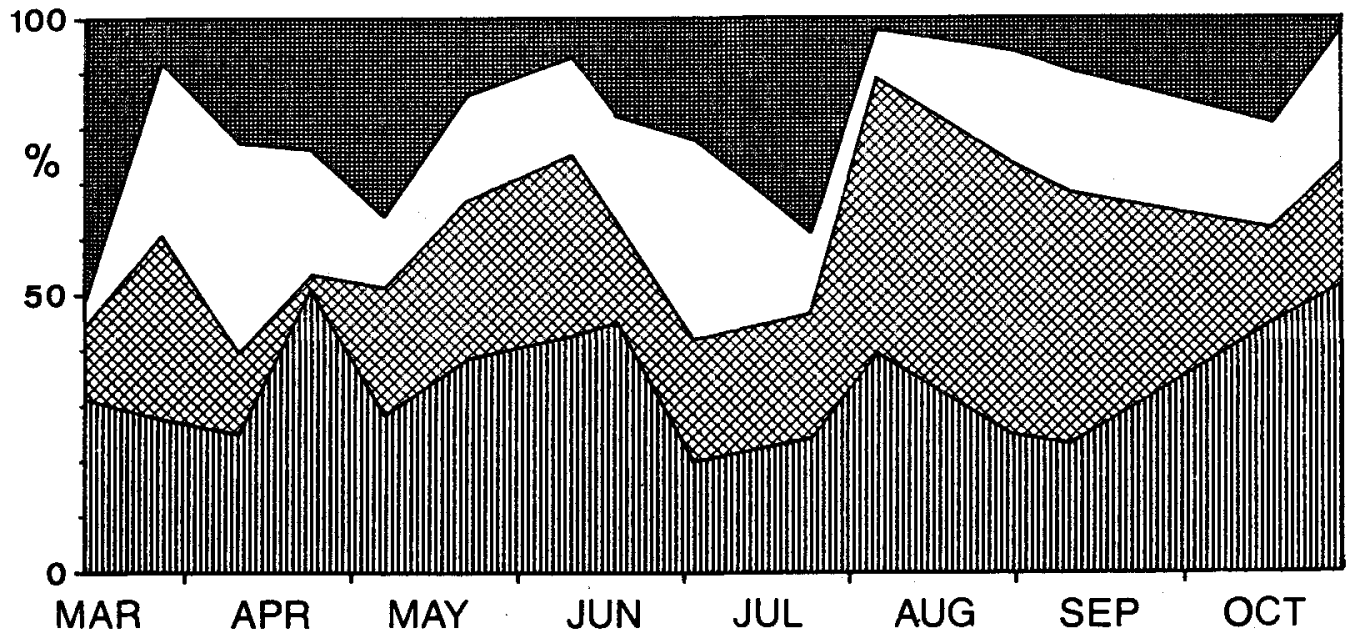

Fig. 3. Carbon uptake of size fractions respectively smaller than 5,20 and $50 \mu \mathrm{m}$ as a percentage of the $150 \mu \mathrm{m}$ fraction.

below 0,5 meter depth. For the 5th of August, the daily column production for the size fractions $<50$ and $<20 \mu \mathrm{m}$ was 98 and $89 \%$ of the $150 \mu \mathrm{m}$ fraction, respectively (Table 3).

\section{DISCUSSION}

The contribution of the various size fractions to the total phytoplankton production was large in Lake Maarsseveen, and in many cases, comparable with data from literature (KALFF, 1972; McCARTHY et al., 1974; MUNAWAR and FAHNENSTIEL, 1982; RAI, 1982; RINGELBERG, 1981b; SKJOLDAL and LANNERGREN, 1978).

During summer, measurements of the $P-I$ curves of the various size fractions occasionally yielded a P-max for the 50 and $20 \mu \mathrm{m}$ fraction which was more than $100 \%$ of the $<150 \mu \mathrm{m}$ phytoplankton size fraction (Fig. 4). This cannot be caused by differences in biomass, since it cannot be reasonably expected that the smaller size fractions contain more algal cells than the total sample. The hypothesis that this is caused by nutrient competition between net- and nanoplankton is not valid, considering the greater efficiency of nutrient utilization by small nanoplanktonic algae in comparison with bigger net plankton (shorter turnover time, higher cell surface/volume ratios) (GLIWICZ and HILLBRICHT.

ILKOWSKA, 1972). Moreover, during the months of July and August, the entire phytoplankton assemblage was dominated by the nanoplankton to the extent of $90 \%$ and more. Most likely, the phenomenon is a consequence of pre-screening the samples, as was done by McCARTHY et al. (1974). These authors have al so measured carbon uptake with post-screened samples and found this uptake consistently lower than production determined with pre-screened fractions. In addition to speculating about differences in fitness or damage of the cells caused by pre- or post-screening, these authors also suggested that the difference could be due to grazing. TAKAHASHI and BIENFANG (1983) have compared the effects of size 


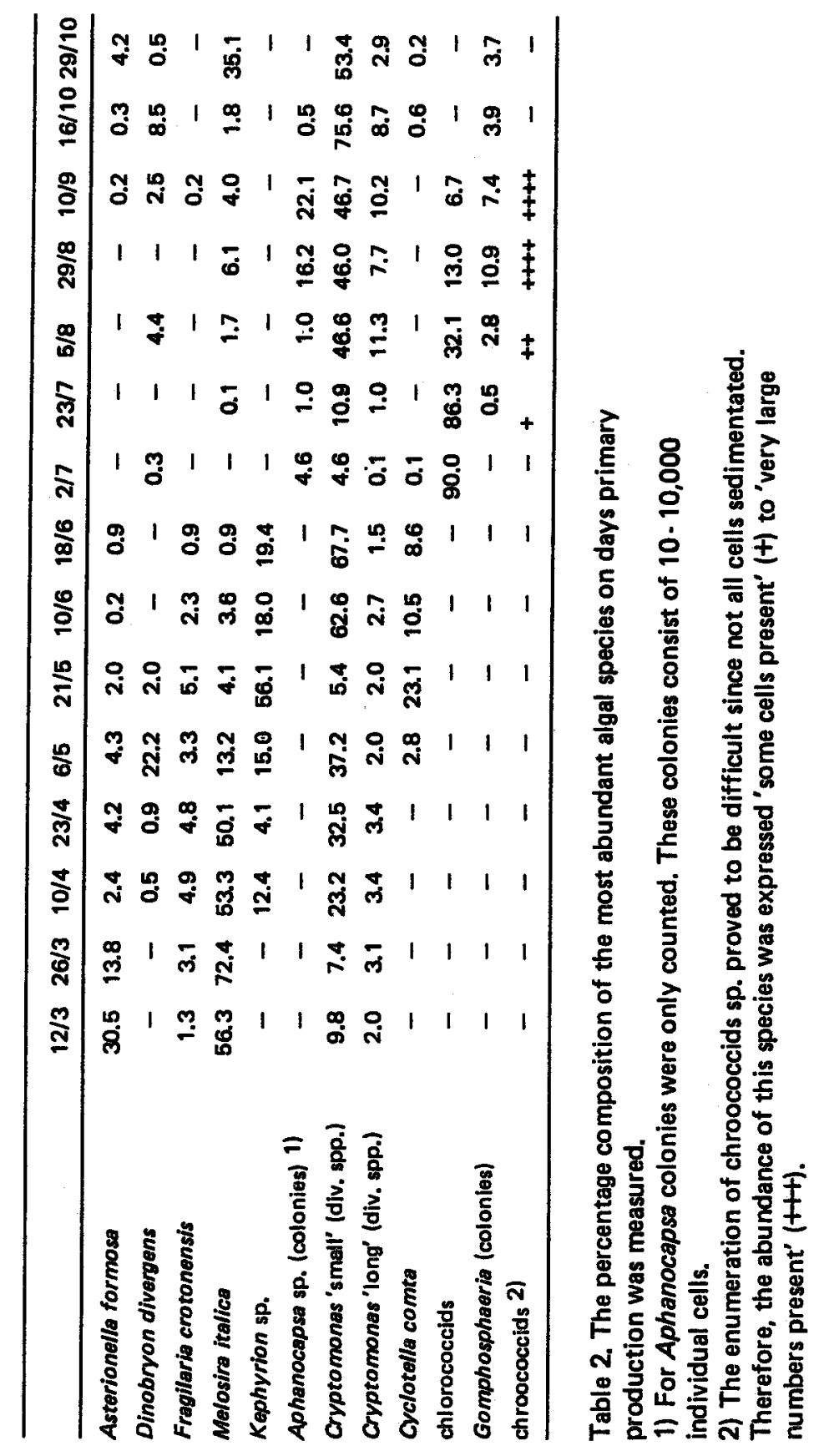




\begin{tabular}{lcccc}
\hline & $<150$ & $<50$ & $<20$ & $<5$ \\
& $a$ & $a$ & $a$ & $a$ \\
Depth In m. & 0.0085 & 0.0036 & 0.0042 & 0.0134 \\
\hline 0.5 & 142.5 & 149.6 & 142.9 & 52.9 \\
1.5 & 148.4 & 146.7 & 138.2 & 54.9 \\
2.5 & 100.5 & 94.8 & 81.6 & 40.9 \\
3.5 & 52.2 & 47.8 & 38.8 & 23.0 \\
4.5 & 23.7 & 21.4 & 16.9 & 10.9 \\
5.5 & 10.2 & 9.0 & 7.1 & 4.8 \\
6.5 & 4.2 & 3.8 & 2.9 & 2.0 \\
7.5 & 1.8 & 1.6 & 1.2 & 0.8 \\
8.5 & 0.7 & 0.6 & 0.5 & 0.3 \\
9.5 & 0.3 & 0.25 & 0.2 & 0.1 \\
Total & 484.5 & 475.5 & 430.3 & 190.6 \\
\% & 100 & 98 & 89 & 39 \\
\hline
\end{tabular}

Table 3. Daily primary production in $\mathrm{mg} \mathrm{C}^{\mathrm{C}} \mathrm{m}^{-3}$. day-1 on the 5 th of August.

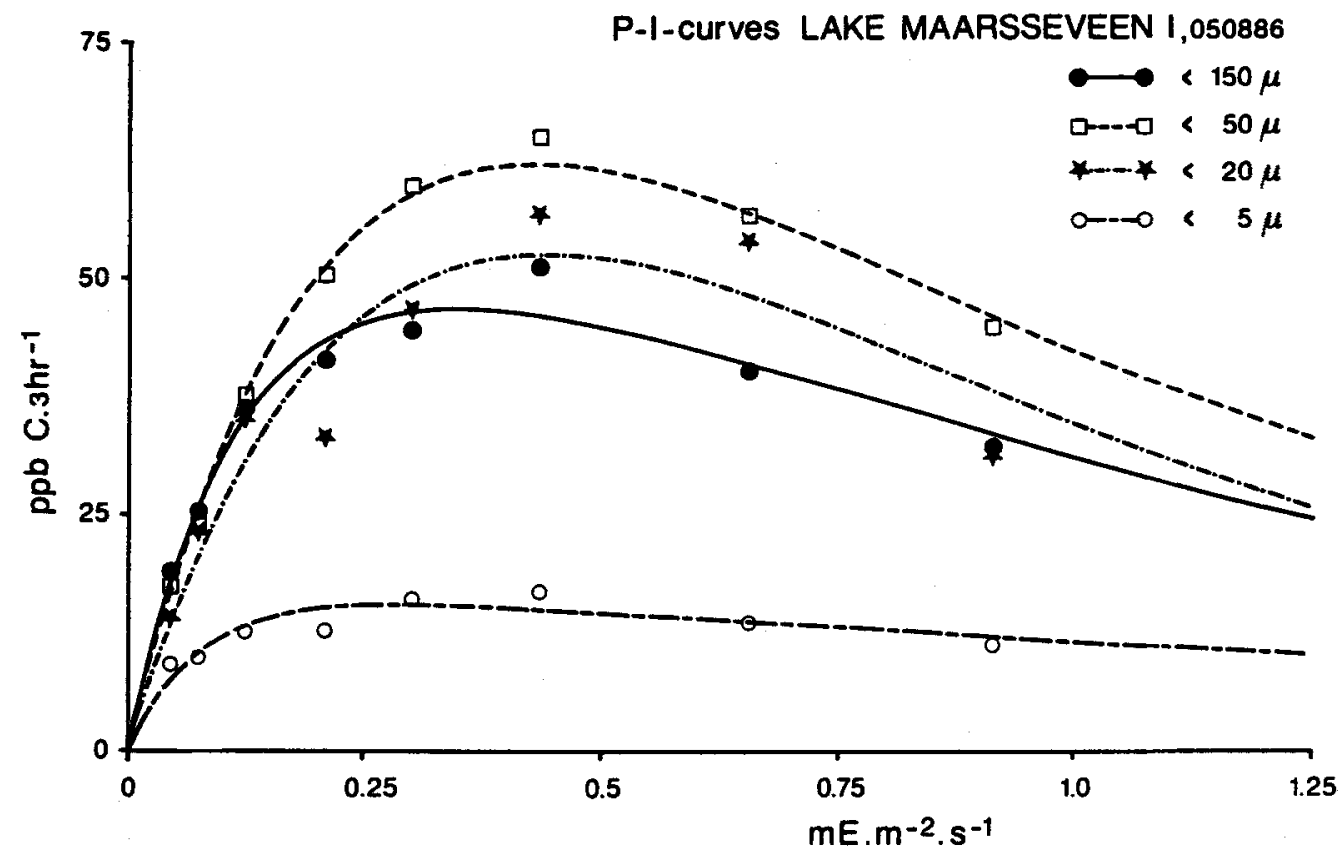

Fig. 4. Carbon uptake of the four size fractions as a function of irradiation during 3 hours. 
fractionation before and after incubation of the size fractions $<3,3.20$ and $20.40 \mu \mathrm{m}$ but no significant differences were found.

This result suggests that fitness or damage of the algal cells cannot be at the base of the phenomenon. However, TAKAHASHI and BIENFANG (1983) used a $<40 \mu \mathrm{m}$ fraction and McCARTHY et al., 1974 a $<163 \mu \mathrm{m}$ size fraction of algae. Some zooplankton species easily pass through mesh sizes of 160 or $150 \mu \mathrm{m}$ but are retained effectively by nets or filters with mesh sizes smaller than $50 \mu \mathrm{m}$. Therefore, the difference between the total phytoplankton sample (even after filtration through $150 \mu \mathrm{m}$ mesh) and the $50 \mu \mathrm{m}$ fraction may be the presence of small zooplankton fraction such as rotifers. According to MORGAN (1980), these small zooplanktons eat nanoplankton and therefore, can change the algal composition in the larger 150 or $163 \mu \mathrm{m}$ size fractions. During the summer period, several species of rotifers, e.g. Kellicottia, Keratella, Polyarthra and Conochilus are present in Lake Maarsseveen (BUTTER et al., 1980; VAN DEN BOSCH and RINGELBERG, 1985) in concentrations up to 300 individuals per liter. With this concentration present and a clearance rate of ca. $10 \mu$ l.animal-1 $\mathrm{h}^{-1}$, as mentioned by STARKWEATHER (1980) for Brachionus Sp., about $10 \%$ of a $100 \mathrm{ml}$ test bottle can be filtered during an incubation period of 3 hours. If this impact is validated, it will yield an underestimate in total phytoplankton productivity, but a correct estimate for the productivity of the size fractions smaller then $50 \mu \mathrm{m}$. Obviously, the impact of grazing by rotifers cannot be ignored in primary production studies. Samples for the measurement of total primary productivity should not only be filtered through $150 \mu \mathrm{m}$ mesh to remove the larger zooplankton organisms, but should also be anaesthetized (GLIWICZ, 1968) to obviate the impact of the smaller zooplankton.

\section{ACKNOWLEDGEMENTS}

We are very indebted to Dik Lindenaar who has taken care of the sampling in the field and to Prof. Dr. W.R. Swain for his critical reading of the manuscript.

\section{REFERENCES}

BRUNO, STEPHEN F., ROBERT D. STAKER, GURDIAL M. SHARMA and JEFFERSON T. TURNER, 1983. Primary productivity and phytoplankton dominance in a temperate North Atlantic estuary. Estuaries, 6: 200-211.

BUTTER, M., J. DORGELO and A. KEYSER, 1980. Zooplankton. In: Limnological research in the Maarsseveen Lakes, 1975-1980, Ed. J. Ringelberg, p. 93-111, Dept. Aquatic Ecology, University of Amsterdam.

DE ROOS, A.M. and B.J.G. FLIK, 1985. Modelling time-series of photosynthesis and comparisons with the fluorescence yield in Chlorella vulgaris : a study of adaptation, inhibition and recovery. J. Plankton Res., 7: 665- 677.

DURBIN, E.G., R.W. KRAWIEC and T.J. SMAYDA, 1975. Seasonal studies on the relative importance of different size fractions of phytoplankton in Narraganset Bay (USA). Mar. Biol., 32: 271 - 287.

FLIK, B.J.G. and A. KEYSER, 1981. Estimation of the primary production in Lake Maarsseveen I with an incubator technique. Hydrobiol. Bull., 15: $41-50$.

FLIK, BEN J.G., 1986. Analysis of the shape of $P$ vs I curves of a natural phytoplankton assemblage during the year in the mesotrophic Lake Maarsseveen I (The Netherlands). Hydrobiol. Bull., 19: 117 - 122.

GLIWICZ, ZBIGNIEW MACIEJ, 1968. The use of anaesthetizing substance in studies on the food habits of zooplankton communities. Ekol. Polska., Ser. A., 16: 279-295.

GLIWICZ, Z.M., 1969. Studies on the feeding of pelagic zooplankton in lakes with varying trophy. Ecol. Pol., Ser. A., 17: 1- 46.

GLIWICZ, Z. MACIEJ and ANNA HILLBRICHT-ILKOWSKA, 1972. Efficiency of the utilization of nanoplankton primary production by communities of filter feeding animals measured in situ. Verh. Internat, Verein. Limnol., 18: 197- 203.

GLIWICZ, Z.M., 1975. Effect of zooplankton grazing on photosynthetic activity and composition of phytoplankton. Verh. Int. Verein. Limnol., 19: 1490- 1497. 
HULSMANN, ADRIE D., 1983. Voedsel opname van enige zooplanktonsoorten uit de Grote Maarsseveense Plas. Ph. D. Thesis, University of Amsterdam.

KALFF, J., 1972. Net plankton and nanoplankton production and biomass in a north temperate zone lake. Limnol. Oceanogr., 17: 712-720.

MALONE, THOMAS C. and MIRA B. CHERVIN, 1979. The production and fate of phytoplankton size fractions in the plume of the Hudson River, New York Bight. Limnol. Oceanogr., 24: 683-696.

McCARTHY, J.J., W. ROWLAND TAYLOR and M.E. LOFTUS, 1974. Significance of nanoplankton in the Chesapeake Bay estuary and problems associated with the measurement of nanoplankton productivity. Mar. Biol., 24: 7-16.

MORGAN, N.C. et al., 1980. Secondary production. In : The functioning of freshwater ecosystems, Eds. E.D. le Cren and R.H. Lowe-McConnell, p. 247-340. Cambridge University Press.

MUNAWAR, M. and G.L FAHNENSTIEL, 1982. The abundance and significance of ultraplankton and micro-algae at an offshore station in central Lake Superior. Canadian Technical Report of Fisheries and Aquatic Sciences. Nr. 1153.

PAVONI, MARIANNE, 1963. Die Bedeutung des Nanoplanktons im Vergleich zum Netzplankton. Schweiz. Z. Hydrol., 25: $219-341$.

PORTER, K.G., 1973. Selective grazing and differential digestion of algae by zooplankton. Natu re, 244: $179-180$.

RAI. HAKUMAT., 1982. Primary production of various size fractions of natural phytoplankton communities in a North German Lake. Arch. Hydrobiol., 95: 395- 412.

RINGELBERG, J., 1981a. Lake Maarsseveen I. Introduction to the research area. Hydrobiol. Bull., 15: $5-9$.

RINGELBERG, J., 1981b. A diel study in a water column of Lake Maarsseveen I. Hydrobiol. Bull., 15: $60-72$.

SKJOLDAL, H.R. and C. LÄNNERGREN, 1978. The spring phytoplankton bloom in Lindosspollene, a land-locked Norwegian fjord. II Biomass and activity of net- and nanoplankton. Mar. Biol., 47: 313- 323.

STARKWEATHER, PETER L, 1980. Aspects of the feeding behaviour and trophic ecology of suspension-feeding rotifers. Hydrobiologia 73: 63-72.

TAKAHASHI, M. and P.K. BIENFANG, 1983. Size structure of phy toplankton biomass and photosynthesis in subtropical Hawailan waters. Mar. Biol., 76: 203-211.

VAN DEN BOSCH, FRANK and J. RINGELBERG, 1985. Seasonal succession and population dynamics of Keratel/a cochlearis (Ehrb.) and Kellicottia longispina (Kellicott) in Lake Maarsseveen I (The Netherlands). Arch. Hydrobiol., 103: 273-290.

VERMIJ, S.G. and FLIK, B.J.G., 1983. An improved model for computing production under high light conditions. Hydrobiol. Bull., 17: 29 - 51.

VERMIJ, STEVEN G., BEN J.G. FLIK and MACHTELD RIJKEBOER, 1985. The influence of photoinhibition on the estimation of daily production computed from photosynthesis-light response curves determined in an incubator. Int. Rev. ges. Hydrobiol., 70: $309-324$.

Address of the authors :

Vakgroep Aquatische Oecologie, Universiteit van Amsterdam, Kruislaan 320, 1098 SM

Amsterdam, The Netherlands. 